\title{
Čovjek u razvojnom stadiju zametka
}

\author{
Mirjana Radan*
}

\begin{abstract}
Sažetak
Unatoč deklarativnoj zaštićenosti ljudske osobe i njezinih primarnih konstitucionalnih prava na život, zagarantiranih brojnim konvencijama i deklaracijama, ontološki status ljudskog zametka osporavan je u svojem prenatalnom stadiju različitim bioetičkim i antropološkim paradigmama, kako bi se njime moglo autonomno raspolagati raznoraznim pragmatičnim interesima prava na samoopredjeljenje ili pak u biomedicinskim istraživanjima.

Cilj je rada ukazati da je čovjek biće iznimne biološke ljepote, nepovredivosti, svetosti i dostojanstva te da se njegov život i zdravlje ne smiju narušavati bioetički neprihvatljivim metodama ljudske reprodukcije. Na temelju znanstvenih, stručnih i iskustvenih općeljudskih čimbenika, na temelju višerazinskog (tijelo, psiha, duh), međudisciplinarnog proučavanja (ravnopravnog dijaloga različitih znanosti), omjera koristi i štete (cost-benefit, isplativost) koje uzrokuju, na temelju zdravorazumskog promišljanja, suusmjeravanja (konvergencije) različitih čimbenika prema istomu žarištu promatranja ljudskog bića, nužna je zaštita čovjeka od rođenja do naravne mu smrti.

Ključne riječi: ljudski zametak, razvoj čovjeka, dostojanstvo ljudske reprodukcije
\end{abstract}

\section{Uvod}

Ljudski je život u svojem prvom razdoblju, u kojem se odvija u majčinu tijelu i u kojem se ljudsko biće naziva embrijem i fetusom, s biološkog i medicinskog vidika najranjiviji, a s etičkog vidika najosjetljiviji. ${ }^{1}$ Iako je čovjek stvoreno tjelesno-duševno-duhovno biće, iznimne izvorne ljepote i dostojanstva, vrijedno divljenja, uvažavanja i poštovanja, mnogi znanstveno-retorički, bioetički i pravni okviri pokušavaju nijekati osobnost ljudskosti u ranim stadijima njegova razvoja.

* Dr. sc. Mirjana Radan, dr. med, Odjel ginekologije i porodništva, ŽB Čakovec, Sveučilište u Zagrebu — Fakultet filozofije i religijskih znanosti. Adresa: Jordanovac 110, 10000 Zagreb, Hrvatska. E-pošta: mirjana.radan@gmail.com

1 A. Švajger, Status ljudskog embrija, u: Ž. Znidarčić (ur.), Medicinska etika 1, Zagreb, 2004, 17. 
Problematika početka individualnog ljudskog života posebno dolazi do izražaja u nizu propitkivanja suvremenih filozofskih, pravničkih i bioetičkih rasprava, od koje, nažalost, nije pošteđena ni sama medicina. Najočitije manipulacije nepriznatog statusa ljudske osobnosti uviđamo na području reproduktivne medicine i prenatalne dijagnostike.

Kada govorimo o embriologiji, sve nedoumice proizlaze iz pitanja: kada počinje život? Pitanje je to na koje ne možemo naći jednoznačan odgovor u pluralizmu različitih stajališta. Biološki gledano, životni ciklus čovjeka odvija se kontinuirano i postupno kroz brojne faze, od kojih se mogu razgraničiti samo dvije. Prva je razvoj unutar tijela majke (od oplodnje do rođenja), a druga je razvoj nakon rođenja.

Ispravno postavljena pitanja stoga glase: Tko je zametak? Tko je čovjek?, a ne: Što je zametak? Što je čovjek? Odgovore na takva pitanja među ostalim znanostima pruža antropologija, osobito filozofska, koja s obzirom da promatra čovjeka u svjetlu filozofskih načela i vrijednosti, pozvana je govoriti o tome »tko je« čovjek u svojoj biti, o njegovoj složenosti i dostojanstvu te je kao takva središte bioetike. $^{2}$ To je osobito važno naglasiti u svim onim bioetičkim pitanjima u vezi s narušavanjem ljudskog dostojanstva i etičke norme po kojoj ljudska osoba nikada ne smije biti upotrijebljena kao sredstvo, a još manje kao ne-ontološka kategorija zanijekanog prava na život. ${ }^{3}$

Na temelju razvojnih stadija zametka, prema znanstvenim dokazima, moguće je točno opisati elemente njegova razvoja. Nužno ga je promatrati vremenski i prostorno u nedjeljivoj prožetosti tijela, psihe i duha pod vidikom ljudske osobe. Ti čimbenici neizostavno pomažu promicanju pravne zaštite čovjeka kroz čitav njegov životni tijek, od rođenja do naravne mu smrti.

\section{1. Čovjek je vremensko i prostorno biće}

Unatoč neospornim biološkim, utvrdljivim empirijskim činjenicama embrionalnog neprekidnog razvoja, njegove individualnosti, jedinstvenosti, neponovljivosti, gradualnosti, kontinuiteta i koordiniranog razvoja, svjedoci smo da se iz različitih pragmatičkih interesa niječe antropološki status osobnosti samog embrija do određenih razvojnih i/li vremenskih uvjetovanosti. Zbog čestog vremenskog nijekanja početka ljudskog postojanja, posljedičnih velikih nesporazuma i nepravdi za čovjeka te neupitnog utjecaja takvih krivih shvaćanja na bioetičku prosudbu ljudske reprodukcije, postavlja se osnovno pitanje: Kada čovjek postaje čovjekom - u trenutku začeća, za vrijeme trudnoće, rađanjem ili

2 Usp. I. Karlić, Tko je čovjek?: neki odgovori suvremene kulture, Filozofska istraživanja, 23/3 (2003), 703-715.

3 Usp. T. Matulić, Oblikovanje identiteta bioetičke discipline: Etička svijest odgovornosti za opstanak u budućnosti, Zagreb, 2011, 215-216. (Poznato je da se zametci koriste u pokusima, za tržište, kao sredstva za uljepšavanje u kozmetičkim industrijama i slično.) 
poslije rođenja? ${ }^{4}$ Neki mu niječu osobnost i antropološki identitet do određenih razvojnih pojavnosti (do stadija primitivne strije, razvoja kore velikog mozga, otkucaja srca, završenom organogenezom, rođenjem i dr.). ${ }^{5}$

Zamišljanje velikog sata na kojem uskoro otkucava ponoć i promatranje kazaljki koje to pokazuju nudi odgovor na postavljeno pitanje. Dakle, kada na promatranom satu otkuca ponoć, pitanje je: što će se to bitno promijeniti kod ljudskog zametka tijekom prijelaza od jedne sekunde ili jedne minute iz prethodnog u novi dan? Što se zapravo dogodilo u promatranoj ljudskoj jedinki da se ona prije toga, biološki gledano, ne smatra čovjekom te je se može bez zakonskih kazni mirno ukloniti sa »scene « života? Kako je moguće da za jednu minutu zametak naglo postaje čovjekom te ga se više ne može odstraniti bez sankcija, bez kazni? Odnosno, zašto ga zakon kao čovjeka štiti tek »od ponoći«, tj. od nekog dogovorenog vremenskog razgraničenja — od navršenih 10 ili 12 tjedana unutarmaterničnog života ili od samog rođenja? Što je bitno drugačije? ${ }^{6}$ Stoga se može postaviti biokemijsko i posve embriološko pitanje: Po kojem se biološkom zakonu i znanstvenim činjenicama iz ljudskog zametka starog 12 tjedana i jednu minutu razvija priznata ljudska osoba koju se kao takvu ne smije uništiti, a iz zametka starog 11 tjedana i 6 dana se ne razvija čovjek te ga se u skladu sa zakonom (legalno) smije ubiti? ${ }^{7}$ Postavljaju se nužna, ključna pitanja o pravima ljudskog zametka, među kojima i temeljno pravo njegova daljnjeg životnog razvijanja. ${ }^{8}$ Ali ne samo to - kazaljku sata možemo vraćati unatrag u svim vremenskim jedinicama (iz sekunde u sekundu, iz minute u minutu, iz dana u dan, iz tjedna u tjedan) i doći ćemo uvijek do istog zaključka. Ako ništa namjerno (namjerni, artificijelni pobačaj) ili nenamjerno (spontani pobačaj) ne prekine slijed razvojnih oblika (zigota, blastula, morula itd.) takva će se biološka jedinka nakon određenog vremenskog razdoblja razviti u odraslu mušku ili žensku osobu - u zrelog čovjeka. ${ }^{9}$

Znanstveno se može tvrditi da kao što mu nedostaje zrelost s 11 tjedana i 6 dana, nedostajat će i s 12 tjedana i jednim danom, s jednom godinom i sa deset godina života. Sva se pitanja i odgovori svode na isti »biološki nazivnik «, činjenicu i tvrdnju — ako čovjek nije čovjek od začeća, od početka svojeg zemaljskog postojanja, od prve sekunde, neće to biti ni na kraju vremenskog života. Pojedine razvojne faze embriološkog stadija ne mijenjaju njegov legitimitet osobe od samog

4 Usp. J. T. Eberl, Thomistic principles and bioethics, London - New York, 2006, 23-42; M. L. Condic, A Biological Definition of the Human Embryo, u: S. Napier (ur.), Persons, Moral Worth, and Embryos: a critical analysis of pro-choice arguments, Dordrecht — New York, 2011, 211-212.

5 Za opširniji pristup, pročitati vrijednu filozofsku raspravu: D. Rupčić, Status ljudskog embrija pod vidom bioetičkog pluriperspektivizma, Zagreb, 2013.

6 Usp. V. Dugalić - I. Rajković, Božji trag u stvorenom, Đakovo, 2010, 37; M. L. Condic, nav. dj., 218-219.

7 U Hrvatskoj i mnogim drugim zemljama, s 12, tj. amenoreje, odnosno izostanka mjesečnice (menstruacije), što se u biti odnosi na 10 tjedana života zametka, zakonski je, uz određeno obrazloženje, dopušten namjerni pobačaj.

8 Usp. C. R. Kaczor, Ethics of abortion: women's rights, human life, and the question of justice, New York, 2011, 121-143.

9 Usp. J. B. Tubbs, Handbook of Bioethics Terms, Washington D. C., 2009, 19. 
trenutka začeća i nema prijelomnih trenutaka u progresivnoj humanizaciji. Naime, u tek oplođenoj jajnoj stanici (zigoti) upisano je sve. Kod je dakle jedinstvena »šifra« čovjeka, u kojoj je upisana i opisana njegova bit već na jednostaničnom stadiju razvoja sa svim mogućnostima koje se tek u vremenu i prostoru polako očituju. ${ }^{10}$ Naime, za svoj rast, razvoj i održanje na životu dijete treba kisik, vodu i hranjive tvari, baš kao što ih treba i odrasla osoba. Prije rođenja, sve potrebno za rast i razvoj dobiva posredovanjem majke (uz pomoć pupkovine) i poslije rođenja (dojenjem). Pri tome, u najranijem stadiju razvoja kao i u uznapredovaloj trudnoći, važno je ne izjednačavati novo ljudsko biće s majčinim tijelom, isto kao što se tijekom daljnjeg rasta i razvoja ono ne smije izjednačavati s okolnim izvorima hrane i pića. Dijete se tijekom svojeg uobičajeno normalnog razvoja nalazi u pravo vrijeme na pravom mjestu. Naime, kao samostojno (autonomno) biće stalno je odvojeno od majčinog sustava organa poput bilo koje odrasle autonomne ljudske osobe u odnosu na životno okružje.

Prostorno gledajući kod »malih trudnoća«, starih svega nekoliko dana ili tjedana, zapravo jedini uvjerljivi pokazatelj stvarnog postojanja trudnoće je pozitivan BHCG test, koji se izvodi u laboratoriju. ${ }^{11}$ Prva potvrda pozitivnog testa i vidljivi dokaz trudnoće prikaz je ploda u materištu pomoću ultrazvučnog aparata. U laboratorijskim je uvjetima oplođena jajna stanica mikroskopski vidljiva. Pomoćni načini dokazivanja trudnoće mogu biti objektivne promjene na tijelu žene, kao i njezin subjektivni osjećaj. Međutim, i to može zavarati u slučajevima kao što je lažna trudnoća (pseudocyesis).

Dakle, konačna se potvrda postojanja trudnoće dobiva tek rađanjem djeteta, očitovanog prelaskom zapravo iz jednog u drugi prostor — iz majke u vidljivi svijet. Isto tako, ako se ne vide nečiji osjećaji ili misli, znači li uistinu da ih određena prisutna osoba ni nema - da ne osjeća, da ne misli? Zar svijet ne postoji samo zato što ga slijepa osoba ne može vidjeti? Međutim, koji svijet? Jer sljepoća može biti tjelesna, intelektualna i duhovna. Dakle, vidljivost ili nevidljivost čovjeka našemu ljudskomu oku (mozgu) nije dokaz ili mjera o njegovu stvarnom postojanju ili nepostojanju.

\section{2. Čovjek na razvojnom stadiju zametka}

Priznavanjem stanja ljudskog zametka (statusa embrija) od samog začeća ukazuje se na osobu koja ima svoje dostojanstvo i nepovredivost te osnovna prava, među kojima bi trebalo biti prvo i neosporivo, konstitucionalno i ustavno - pravo na život. ${ }^{12}$ Prema ustavnopravnomu uređenju Republike Hrvatske i odredbe

10 Usp. A. W. Müller, The Concept of Person in Bioethics, u: S. Napier (ur.), Persons, Moral Worth, and Embryos: a critical analysis of pro-choice arguments, Dordrecht — New York, 2011, 89-90.

11 Pozitivan BHCG test označava postojanje BHCG-a u tijelu žene (hormona uglavnom svojstvenog trudnoći).

12 Usp. M. Rhonheimer, Ethics of Procreation and the Defense of Human Life: Contraception, Artificial Fertilization, and Abortion, Washington D. C., 2010, 179-187. 
koja navodi da »Svako ljudsko biće ima pravo na život « (čl. 21) pravna teorija pod time podrazumijeva pravo na bogat, osmišljen i smislen, svrhovit život, život koji je dostojan življenja, ostvarivan u pozitivnom međudjelovanju članova obitelji, žene i muža, djece i roditelja te drugih srodnika. Što se tiče ljudskog dostojanstva, tumačenje te odredbe krije dvije zamke: pobačaj i eutanaziju. S jedne strane ljudsko biće svakako podrazumijeva živorođenog čovjeka, za poneke i nerođeno dijete, što znači i zakonsku zabranu pobačaja. S druge strane, shvatimo li »pravo na život« kao pravo na održanje dostojanstva u tom životu, otvaramo vrata eutanaziji, odnosno potrebi za okončanjem nekog navodno nekvalitetnog života koji ne odražava zahtjev za ljudskim dostojanstvom (kao što bi to bio slučaj u pobačaju iz eugeničkih ili terapeutskih indikacija). Međutim, vrlo je važno uočiti kako je ljudski život neraskidivo povezan s ljudskim dostojanstvom ${ }^{13}$ (shvaćenim ne samo kao kakvoća — riječ vrlo rastezljiva i relativna značenja), nego kao zadanost, na način da je ljudsko dostojanstvo istoznačno s ljudskim životom. ${ }^{14}$

Na njemu se temelje sva ostala izvedena prava, poput prava na liječenje, te ostvarivanje svih uvjeta potrebnih za normalan rast i razvoj. Naravno pravo čovjeku pripada po samoj njegovoj prirodi (naravi). Pripada mu baš zato što je čovjek. Ni jedan drugi čovjek ne može mu ga dodati ni oduzeti. Osnovno ljudsko pravo je pravo na život. Iz njega proizlaze sva druga prava. Razvojni stadij čovjeka na razini samo jedne stanice (jednostanični stadij razvoja) nastaje spajanjem ${ }^{15}$ gameta (singamijom) i naziva se oplođena jajna stanica ili zigota. ${ }^{16} \mathrm{Ga}$ mete označavaju mušku i žensku spolnu stanicu, spermij i jajašce koji se stapaju u procesu začeća radi razvijanja nove jedinke ljudske vrste - novog čovjeka. Prema znanstvenim podatcima (koje su utvrdile biologija i genetika) zigota posjeduje vlastiti, potpuno individualni genom različit od onog očevog ili majčinog. $\mathrm{Na}$ putu iz jajovoda u materište zametak (embrij) se iz stadija zigote daljnjim razvojem preobražava u morulu i blastulu.${ }^{17}$ Priljubljivanjem blastule neposredno uz unutarnju stijenku maternice započinje usađivanje (nidacija, implantacija), odnosno ugnježđenje ljudskog zametka u sluznicu maternice. Dakle, ljudski zametak je jedinka koja tijekom razvoja u majčinoj utrobi prolazi različite faze sazrijevanja i rasta uvijek istim slijedom, bez skokova i prekida. ${ }^{18}$ Tako postoji zametak u stadiju zigote, zametak u stadiju morule i zametak u stadiju blastule. Embriološki ${ }^{19}$ period završava razvojem osnove svih organa (organogeneza).

13 Usp. I. Koprek, Ljudsko dostojanstvo - mjesto dijaloga vjere i razuma, u: B. Vuleta - A. Vučković - I. Milanović (ur.), Dijalogom do mira - Zbornik radova u čast dr. Željku Mardešiću, Split, 2005, 109-122.

14 Usp. D. Hrabar, Deontološka prosudba ljudskog dostojanstva u obiteljskom pravu, Bogoslovska smotra, 77/1 (2007), 33; M. Rhonheimer, nav. dj., 212-216.

15 Usp. M. L. Condic, nav. dj., 219.

16 Usp. F. J. Beckwith, The Explanatory Power of the Substance View of Persons, Christian Bioethics, 10/1 (2004), 50-52.

17 Usp. M. L. Condic, nav. dj., 220-222.

18 Isto, 211-235.

19 Embriologija je grana biologije koja se bavi proučavanjem zametka i njegova razvoja. Usp. R. Cammack i dr. (ur.), Oxford Dictionary of Biochemistry and Molecular Biology, Oxford, 2006, 213. 
Prije bilo kojeg filozofskog, medicinskog ili bioetičkog promišljanja o tome kada nastaje ljudski život, ${ }^{20}$ važno je razjasniti i uskladiti pojmove kako bi se spriječili nesporazumi, zloporabe, nepravde i neistine učinjene čovjeku u najranijoj mu fazi razvoja, a nastale čestim, namjernim mijenjanjem i prilagođavanjem nazivlja (terminologije), što po svojoj biti spada u »lingvističko inženjerstvo«.21 To se osobito odnosi na naziv »predzametak ili preembrij «, ${ }^{22}$ kojeg neki tako embriološki nazivaju tek nakon 15. dana, kada se uočava primitivna pruga (brazda), ${ }^{23}$ što je posve nelogično, netočno i bez ikakvog biološkog, genetičkog, epigenetičkog ili filozofskog utemeljenja, dakle više iz ideoloških razloga. ${ }^{24}$ Znanstvena je i uopće poznata činjenica da ne postoji neki biološki stadij koji bi prethodio zametku ili bi ga slijedio, jer on nastaje spajanjem gameta, a rezultira rođenjem djeteta. Tijekom unutarmaterničnog (intrauterinog) razvoja zametka neprekinutim daljnjim slijedom čovjek prolazi razvojnu fazu fetusa, koja traje sve do njegova rođenja. ${ }^{25}$ Nakon rođenja isti je čovjek i dalje vidljiv kao novorođenče, dojenče, predškolsko i školsko dijete, zatim u pubertetu, kao adolescent, zreo, odrastao čovjek te kao osoba srednje i starije životne dobi. ${ }^{26} \mathrm{Tu}$ je riječ o različitim razvojnim fazama unutar iste ljudske vrste, ${ }^{27}$ jer oboje (zigota i zametak) pripadaju ranim stadijima ljudskog razvoja. Tu nisu u pitanju različite vrste živih bića, po čemu bi zigota pripadala jednoj, a ljudski zametak drugoj vrsti.

Zigota ima potpuno drugačiji genom u odnosu na oca ili majku, jer nastaje spajanjem ${ }^{28}$ spermija (23 očeva kromosoma) s jajašcem (23 majčina kromosoma) te predstavlja novi organizam (ne više samo gametu, odnosno jednu majčinu ili očevu spolnu stanicu) s potpunim brojem od 46 kromosoma svojstvenih čovjeku. ${ }^{29}$ Znanost, dakle, tvrdi da je zigota novi organizam. ${ }^{30}$

Prije oplodnje spermatozoid (zrela muška spolna stanica) i jajna stanica posjeduju mogućnost osnivanja jednog jedinstvenog entiteta. Zigota (oplođena jajna stanica) je naprotiv individuum obdaren vlastitim životom i identitetom dobivenim od jedinstvenog sjedinjavajućeg načela. Bitno kvalitativan skok događa se prijelazom dviju supstancija, među kojima postoji puka vanjska relacija (gamete), u jednu jedinstvenu

20 Usp. I. Kešina, Čovjek između prokreacije i proizvodnje: Kršćanska etika ljudskog rađanja, Split, 2008, 37-62.

21 Usp. V. Pozaić, Bio-etika i bio-politika, Obnovljeni život, 60/1 (2005), 87.

22 Usp. I. Fuček, Moralno-duhovni život, sv. 1., Osoba savjest, Split, 2006, 25; M. Rhonheimer, nav. dj., 202; M. L. Condic, nav. dj., 214-217.

23 Primitivna pruga je izraz iz razvojne biologije koji kod ljudskog zametka označava izduženu skupinu gusto zbijenih stanica u njegovu razvojnom stadiju (gastrulacija) koje svojim gibanjem (epiblasta) čine osnovu (endoderma, mezoderma) pojedinih vrsta tkiva. Usp. T. W. Sadler, Langman's Medical Embryology, Philadelphia, 2012, 367.

24 Usp. F. J. Beckwith, nav. dj., 45-49.

25 Usp. J. B. Tubbs, nav. dj., 48-49.

26 Usp. M. Rhonheimer, nav. dj., 27.

27 Usp. Isto, 187-192.

28 Usp. M. L. Condic, nav. dj., 212-213.

29 N. P. G. Austriaco, Complete Moles and Parthenotes Are Not Organisms, u: A. Suarez - J. Huarte (ur.), Is this Cell a Human Being? Heidelberg — New York, 2011, 45-54.

30 Usp. R. Lucas Lucas, Bioetika za svakoga, Split, 2007, 118. 
supstanciju (zigota). Samo oplodnjom ili začećem počinje postojati i stvarno postojati čovjek. ${ }^{31}$

Taj novi organizam je ljudski organizam zbog broja i prirode kromosoma karakterističnih za ljudsku vrstu (žena 46XX ili muškarac 46XY). Čovjeka obilježava upravo takav broj i narav kromosoma, kao što druge vrste imaju drugi broj i vrstu kromosoma karakterističnih baš za te vrste. Biološki su zakoni nepromjenjivi i jasno je da nema prijelaza ni naravnog miješanja među određenim vrstama. Od pojedinih životinja nastaju životinje te vrste (od psa pas, od mačke mačka), isto kao što od čovjeka nastaje samo čovjek i ništa drugo. ${ }^{32} \mathrm{U}$ odnosu na ostale vrste, čovjek je pri rođenju dobio najmanje sposobnosti, zbog čega je kao veoma bespomoćno i krhko biće ovisno o brizi okoline. Međutim, po razvojnim mogućnostima (potencijalima) i prilagodljivosti, po onom što je zapisano i određeno u njegovim genima, ako mu se omoguće obiteljski, društveni i drugi uvjeti rasta i razvoja, čovjek postiže najviše ostvarenje. ${ }^{33}$ Znanost, dakle, tvrdi da je zigota, ljudski organizam. ${ }^{34}$ Zigota kao ljudsko biće ima jedinstven genom, odnosno »formulu i program«. Nije jednostavan zbroj očevih i majčinih genetskih kodova, nego je biće sa zadanim novim nacrtom i novim programom (jedinstvenim genomom). ${ }^{35}$ Po njemu se polako oblikuje u zrelog čovjeka koji nikada do tada nije postojao, niti će se ikada više ponoviti. Znanost, dakle, tvrdi da je zigota genetski programiran organizam, upisan u 46 njegovih kromosoma. ${ }^{36}$

Prema znanstvenim dokazima zametak pokazuje četiri osobine razvoja:

a) Biološko jedinstvo (unitivnost) novog bića, koje je označeno skladnim i povezanim razvijanjem svih dijelova zametka, kao sastavnice jedne nedjeljive biološke cjeline. ${ }^{37}$ Individualnost zigote je razvojna individualnost pa je zato zigota stvarno (realno), a ne tek potencijalno novo ljudsko biće, i to bez obzira na moguću kasniju sudbinu (razvoj do rođenja, razdvajanje u monozigotne blizance, intrauterina smrt). ${ }^{38}$

b) Usklađenost svih aktivnosti (koordinacija) ljudskog zametka, odnosno njihova međusobna povezanost i posljedično jedinstvo. ${ }^{39}$ To znači da čak i u svojim najranijim fazama čovjek nije samo skup stanica, nego je neponovljiva jedinka, pojedinac, u kojem su umnažajuće stanice usko povezane (integrirane) u proces

31 Usp. V. Valjan, Ljudsko biće od začeća: međudisciplinarni pristup, Bosna francisiana, 5 (1996), 68.

32 Usp. M. Rhonheimer, nav. dj., 192; V. Valjan, nav. dj., 68; M. L. Condic, nav. dj., 222-223.

33 Usp. M. L. Condic, nav. dj., 229-232; J. T. Eberl - B. P. Brown, Brain Life and the Argument from Potential: Affirming the Ontological Status of Human Embryos and Fetuses, u: S. Napier (ur.), Persons, Moral Worth, and Embryos: a critical analysis of pro-choice arguments, London New York, 2011, 50-55.

34 Usp. R. Lucas Lucas, nav. dj., 118.

35 Usp. V. Dugalić, I. Rajković, nav. dj., 36.

36 Usp. M. L. Condic, nav. dj., 223-224.

37 Usp. A. C. MacIntyre, After virtue: a study in moral theory, Notre Dame, 2007, 204-225.

38 Hrvatska biskupska konferencija. Vijeće za obitelj, A. Volarić-Mršić (ur.), Status ljudskog embrija, Zagreb, 2001, 20.

39 Usp. J. T. Eberl - B. P. Brown, nav. dj., 48. 
njegova sve većeg i vidljivog oblikovanja. ${ }^{40}$ Ako ga ništa ne spriječi, zametak po zadanom i upisanom genetičkom nacrtu, polako i sigurno, ostvaruje ono što mu je od početka poklonjeno u malom, sitnom, jedinstvenom, ali cjelovitom postojanju čovjeka od začeća. ${ }^{41}$

c) Neprekinutost (kontinuitet) i nužnost razvoja ljudskog zametka, kad jednom započne život pomoću kojeg postupno, stupnjevito nastaje zreo čovjek, a ne neko drugo neljudsko biće. ${ }^{42}$ Stoga, ne postoje kvalitativni skokovi ${ }^{43}$ i bitne razvojne promjene u smislu vrste, što jasno upućuje na uvijek isti subjekt, odnosno čovjeka, koji to jest od začeća, od zigote pa sve do prirodnog ili nasilnog završetka njegova životnog ciklusa — do same smrti.

d) Postupnost (sukcesivnost) razvoja ljudskog zametka, kao posljednja ovdje navedena značajka, ukazuje na način postizanja njegova konačnog izgleda. Razvoj čovjeka označava slijed oblika, tj. stadija u različitim trenutcima jednog istog procesa njegova nastajanja. Zato zametak vremenom stalno zadržava svoju prepoznatljivost (identitet), osobnost (individualnost) i jedinstvenost (uniformnost), ostajući kroz cijeli proces razvoja uvijek jedan isti pojedinac. ${ }^{44}$ Embrionalni razvoj teče kontinuirano, koordinirano i postupno. Zato nijedno pojedinačno zbivanje tijekom razvoja ne znači kvalitativno prijelomnu točku koja bi promijenila narav tog bića, koje je određeno samim začećem. Ono što možemo vidjeti u embrionalnom razvoju od trenutka spajanja gameta pa nadalje proces je koji pokazuje redoslijed i koordiniranu interakciju molekularnih aktivnosti, koje se odvijaju pod kontrolom novog genoma. Ljudski embrij, kao i svaki drugi embrij, nije pusta gomila stanica, nego je čitav embrij stvarna jedinka, gdje su pojedinačne stanice usko povezane uz proces posredstvom kojeg on svoj genetski sastav čas po čas samostalno prevodi u tjelesni organizam..$^{45}$ Osim njegove tjelesno-biološke značajke, embrij ima i svoju nedjeljivu duhovnu komponentu.

\section{3. Čovjek predstavlja jedinstvo tijela, psihe i duha}

Ljudsko biće nije svodivo ni na svoju fizičku dimenziju ni isključivo na svoju duhovno-duševnu dimenziju. »Čovjek je dušom i tijelom $=$ jedno. « ${ }^{46}$ To se promišljanje temelji na postavkama personalističke bioetike i iskustvu po kojem znamo da čovjek ima tijelo, volumen, masu, da zauzima određeni prostor te ga

40 Usp. Isto, 213-214.

41 Usp. M. L. Condic, nav. dj., 224-229.

42 Usp. M. Rhonheimer, nav. dj., 26.

43 Usp. T. Matulić, Neologizam »predembrij« u suvremenoj bioetičkoj diskusiji, Bogoslovska smot$r a, 4,(1996), 635-664$.

44 Usp. I. Fuček, Moralno-duhovni život, sv. 1., Osoba savjest, Split, 2006, 28-35; D. B. Hershenov, Embryos, Four-Dimensionalism, and Moral Status, u: S. Napier (ur.), Persons, moral worth, and embryos, Dordrecht, 2011, 125-144.

45 M. Aramini, Uvod u bioetiku, Zagreb, 2009, 168.

46 Drugi vatikanski koncil, Pastoralna konstitucija Gaudium et Spes - O crkvi u suvremenom svijetu, u: Dokumenti, Zagreb, 2008, br.14. 
se može mjeriti, vagati i opipati. U ostatak vidljivog svijeta uklopljen je po materijalnom organizmu, »ljudskom tijelu« koje predstavlja njegovu osobnost (identitet), posebnost (original) i prvu datost po kojoj se razlikuje od drugih ljudskih bića. Budući da je ljudska duša substancijalna forma i načelo života, duhovna stvarnost nematerijalnog podrijetla, da se njezina prisutnost ne može iskustveno dokazati, podrijetlo se ljudske duše znanstveno ne potvrđuje, a niti ne niječe. ${ }^{47}$ Zbog toga se zaključuje da jedini preostali odgovor nije znanstveno dokumentiran, ali je racionalno dokazan: duhovna duša svakog ljudskog bića izravno je stvorena od Boga, tijekom njezina začeća. ${ }^{48}$ Naime, čovjekov tvorac, Bog, zamislio je čovjeka kao jedinstvo tijela i duše te se služi materijom da bi stvorio ono što je materijalno, a duhovna je stvarnost izravni trag Božje prisutnosti u čovjeku. ${ }^{49}$ Duh zametka ne može biti eksperimentalno viđen, baš kao što to ne može biti ni duh odrasle osobe. Ontološki je prije riječ o kakvoćama osobe koje proizlaze iz duha ili su njime uzrokovane, nego o njihovim opažanjima.

Temeljni se kriterij nalazi u vlastitoj prirodi svakog čovjeka, čak i kad se on još ne očituje ili se privremeno tako ne očituje. Zbog toga pogled na jedinku ljudske vrste dovodi do shvaćanja i priznavanja razumskog bića koje ima ljudsku narav i koje jest osoba jer osoba se poklapa s ljudskim bićem čineći jedinstvo tijela i duše. Pojam osobe izjednačava se s pojmom ljudskog bića te predstavlja jedinstvo tijela i duše, što znači da čovjek nije samo materija, nego je i duh ili, još bolje utjelovljeni duh. ${ }^{50}$ Upravo mu to daje uzvišeno, prirođeno dostojanstvo i neosporivo pravo na život, kako ne bi postao nečije vlasništvo, objekt, sredstvo i oruđe za postizanje bilo kakvih negativnih ciljeva, odnosno ponižavanja, iskorištavanja i instrumentaliziranja njegove osobe..$^{51}$

Ako zametak koji pripada ljudskoj vrsti nije od početka istinska ljudska osoba, on to ne može ni kasnije postati, a da ne proturječi svojemuidentitetu. ${ }^{52}$ Jedinstvo i neprekinutost razvoja zametka kao jedinke ljudske vrste zahtijeva priznanje da je on već od trenutka razvoja stvarno i osobno ljudsko biće. Posve je jasno da je osoba biološki, psihološki i moralno zrelija u odrasloj dobi nego na razvojnom stadiju zametka. Nerođeno je dijete osoba i ima isti moralni status kao rođeno ljudsko biće. ${ }^{53}$

Čovjek je dobio daleko veće razvojne umne mogućnosti, nego što ih uopće uspije upotrijebiti prije svoje smrti. Budući da je sav čovjekov razvoj kodiran,

47 Usp. M. Rhonheimer, nav. dj., 27.

48 Usp. A. Suarez, Is this Cell Entity a Human Being? Neural Activity, Spiritual Soul, and the Status of the Inner Cell Mass and Pluripotent Stem Cells, u: A. Suarez - J. Huarte (ur.), Is this Cell a Human Being? Heidelberg — New York, 2011, 171-192.

49 Usp. M. Rhonheimer, nav. dj., 7-8.

50 Usp. E. Schockenhoff, Koliko je nedodirljivo ljudsko dostojanstvo? Veza između ljudskoga dostojanstva, osobe i naravi na području bioetike, Bogoslovska smotra, 77/1 (2007), 5-21.

51 Usp. D. Evans, Values in medicine: what are we really doing to patients? London - New York, 2008, 119-128.

52 Usp. M. Tooley, Basic Moral Principles and the Concept of a Person, u: H. Kuhse - P. Singer (ur.), Companion to bioethics, Malden, MA, 2009, 129-130.

53 Usp. M. Rhonheimer, nav. dj., 26. 
genetički i okolinski određen od prvog dana života, samo je pitanje vremena kada će se (ako ih ništa ne omete) njegovi pojedini sustavi razviti i funkcionalno do kraja očitovati. Izuzetno je važno uočiti kako se ljudsko sazrijevanje događa uvijek u okviru iste, osobne, vlastite naravi pojedinca, koja je prisutna od prvog časa začeća.

Brojni dokumenti Crkvenog učiteljstva stoje u obrani prava na život i ljudsko dostojanstvo. Enciklika o vrijednosti i nepovredivosti ljudskog života: Evanđelje života ističe da osoba ima vrijednost, jedinstvenost i neponovljivost koja zaslužuje svako poštivanje, posebice kada je nevina i nezaštićena.

Čovjek je pozvan na puninu života koja prilično nadilazi dimenzije njegova zemaljskog postojanja, jer se sastoji u sudjelovanju u samom Božjem životu. Uzvišenost ovog nadnaravnog zvanja objavljuje veličinu i dragocjenost ljudskog života u njegovoj vremenskoj fazi. Život u vremenu, ustvari, je temeljni uvjet, početni moment i sastavni dio čitavog i jedinstvenog procesa ljudskog postojanja. ${ }^{54}$

Osvrćući se na taj papin tekst, možemo vidjeti kako Crkva čovjeka promatra kao osobu koja je stvorena u vremenu te je njezin život usmjeren na konačno vječno. Samim time, ukoliko je život Božji dar, mi nismo ti koji o njemu možemo odlučivati i raščlanjivati njegove faze razbijajući temeljni neprekinuti proces od samog početka - oplodnje, tj. začeća.

Zbor za nauk vjere u Naputku o poštivanju ljudskog života u nastanku i o dostojanstvu rađanja: Dar života napominje da plod ljudskog rađanja, od prvog trenutka svojeg postojanja, od konstituiranja zigote, zahtijeva bezuvjetno poštovanje, zbog ljudskog bića u njegovu tjelesnom i duhovnom totalitetu. »Ljudsko biće treba poštovati i tretirati kao osobu od trenutka začeća, i stoga od tog istog trenutka njegova prava kao osobe moraju biti priznata, među kojima je na prvom mjestu nepovredivo pravo svakog ljudskog bića na život. «55

\section{Zaključak}

Pitanje početka ljudskog života povod je za brojna etička, filozofska, pravna i vjerska pitanja. Znanstveni i tehnološki napredak biomedicine donosi nova saznanja, nove mogućnosti intervencije u prenatalni stadij embrionalnog razvoja, ali istovremeno polučuje i brojna nova pitanja, dok se neka stvaraju zbog različitih interesa i tako izazivaju daljnje duboke etičke podjele.

Ljudsko biće, oduhovljeno tijelo i otjelovljeni duh, nastaje već u prvom trenutku oplodnje. Ostvariti oplodnju, tj. začeće, znači ostvariti novo ljudsko biće, bez obzira kako ga mi nazivali: zigota, blastula, gastrula, morula, proembrij, embrij, fetus ili ljudski plod. Svi ti nazivi označavaju pojedine stadije razvoja, ali mu nikako ne mijenjaju narav, jer je u svakom od tih stadija riječ o jedinstvenom

54 Ivan Pavao II., Enciklika o vrijednosti i nepovredivosti ljudskog života: Evangelium vitae — Evanđelje života, Zagreb, 2003, 6.

55 Kongregacija za nauk vjere, Naputak poštivanju ljudskog života u nastanku i o dostojanstvu rađanja, Donum vitae — Dar života, Zagreb, 1997, 19. 
i neponovljivom, pravom, ljudskom biću. Odvijanje životnog ciklusa, odnosno embrionalnog razvoja, temelji se na razvojnom programu koji je određen novim genomom nastalim spajanjem muške i ženske spolne stanice. Od samog nastanka zigote embrij predstavlja funkcionalno jedinstvo koje se samoorganizira i diferencira. Iz embriološke analize ljudskog razvitka može se opravdano zaključiti da je ljudski embrij od trenutka same oplodnje čovjek i da posjeduje ljudsku egzistenciju.

Doneseni zaključak ne dopušta samovolju u ne-priznavanju ontološkog statusa ljudskog embrija, ni u njegovoj instrumentaliziranoj upotrebi te postavlja stroge granice reproduktivnim tehnologijama i eksperimentalnoj medicini na embrijima, a samim time i jasniju potrebu zakonodavne pravne zaštićenosti statusa ljudskog embrija.

»Od samog začeća život svakog ljudskog bića mora se apsolutno poštivati, jer je čovjek jedini stvor na zemlji kojega je Bog htio radi njega samoga, a duhovnu dušu svakom čovjeku, Bog neposredno stvara; cijelo njegovo biće slika je Stvoritelja.«56

\section{The Human Being in the Embryonic Development Stage}

\section{Mirjana Radan*}

\section{Summary}

Despite the declarative protectedness of the human person and his primary constitutional rights to life guaranteed by multiple conventions and declarations, the ontological status of the human embryo has been disputed in its prenatal stage by various bioethical and anthropological paradigms such that it can be dealt with autonomously by various pragmatic interests of the right to self-determination or in biomedical research.

The aim of this paper is highlight the fact that man is a being of exceptional biological beauty, inviolable sanctity and dignity, and that his life and health must not be tampered with through unacceptable methods of human reproduction. On the basis of scientific, expert and experiential universal human factors, on the basis of multi-level (body, psyche, spirit) interdisciplinary studies (dialogue on an equal level among various sciences), the rate of benefit and harm (cost-benefit) which they cause, on the basis of common sense, the convergence of various factors toward the same focal point of observation of the human being, it is imperative that man be protected from birth to natural death.

Key words: human embryo, development of man, dignity of human reproduction

56 Kongregacija za nauk vjere, Naputak poštivanju ljudskog života u nastanku i o dostojanstvu rađanja, Donum vitae - Dar života, Zagreb, 1997, 5.

* Mirjana Radan, OB/GYN, Ph.D., Čakovec County Hospital, Gynaecology Ward, The Faculty of Philosophy and Religious Studies of The University of Zagreb. Address: Jordanovac 110, 10000 Zagreb, Croatia. E-mail: mirjana.radan@gmail.com 